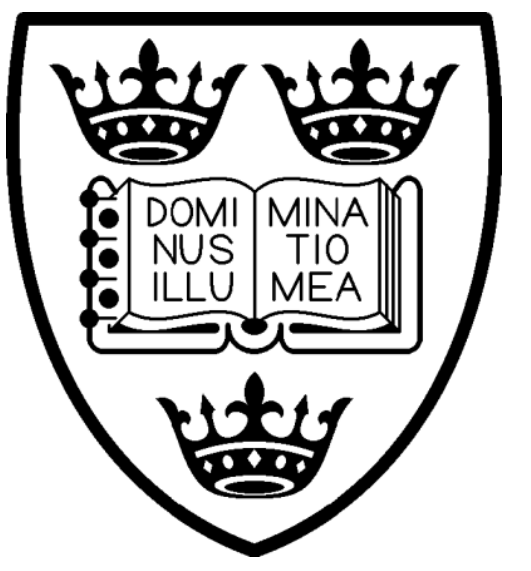

UNIVERSITY OF OXFORD Discussion Papers in Economic and Social History

Number 89, June 2011

THE POLITICAL ECONOMY OF GLOBAL FINANCIAL Liberalisation IN Historical PERSPECTIVE

Rui P. Esteves 


\title{
The Political ECONOMY of GLOBAL FinANCIAL LIBERALISATION IN HISTORICAL PERSPECTIVE
}

\author{
Rui P. Esteves ${ }^{1}$ \\ Department of Economics \\ and \\ Brasenose College \\ University of Oxford \\ Oxford OX1 3UQ \\ <rui.esteves@economics.ox.ac.uk>
}

Forthcoming in The Encyclopedia of Financial Globalization, edited by Gerard Caprio. $^{2}$

\begin{abstract}
This paper is a first attempt to garner the theory and evidence on the political economy of the first wave of financial liberalisation during the nineteenth and early twentieth century, and of its demise after World War I. Not everyone gained from the process of globalisation (of trade, labour, and finance), which brought about important changes in the structure of the economy and the distribution of income in nations across the world. This paper explores how the economic incentives generated by these dislocations translated, through the political system, into choices about openness to foreign capital and financial integration. The period before World War I is remarkable by the almost absence of restrictions on cross-border capital flows, which may explain the little attention it has received in the historical literature, compared to the extensive study of trade protectionism in this period. After the War, many countries experimented with capital controls which varied in nature and intensity and were intensified during the Depression. Despite the attempt made here to reconcile these stylized facts to models of political economy, the analysis requires a better empirical foundation and some suggestions for further research are also proposed.
\end{abstract}

Keywords: political economy, financial liberalisation, capital controls, pre-war JEL codes: F4, G18, N20

\footnotetext{
${ }^{1}$ The author wishes to thank Yanjun Lin and Cornelius Christian for valuable research assistance, Dennis Quinn for generous sharing of data, and Florian Ploeckl for helpful comments.

${ }^{2}$ All rights reserved by the publisher Elsevier Inc.
} 


\section{Introduction.}

This paper discusses the political processes behind the first wave of financial liberalisation during the nineteenth and early twentieth century and its demise after World War I. As we live through a renewed period of financial integration since the 1970s, the question naturally arises about its sustainability and whether we can draw lessons from history. Not everyone gained from the process of globalisation -of trade, labour, and finance-, which brought about important changes in the structure of the economy and the distribution of income in nations across the world. This paper explores how the economic incentives generated by these dislocations translated, through the political system, into choices about openness to foreign capital and financial integration. In this type of study, the logic of political economy is especially useful in cognate contexts, particularly the attitude of countries towards protectionism (Rogowski 1989; Frieden and Rogowski 1996) and the choice of exchange rate regimes (Eichengreen 1992, Gallarotti 1995).

The history of financial openness and liberalisation has been less studied, although there is a vibrant literature on the political drivers of the current process of financial integration. Despite Frieden and Rogowski's (1996: 27) claim that "movements of services and capital are analogous to those in goods and can be subjected to similar tools of analysis," the former have attracted much less attention in the historical literature than the latter. Apart from data limitations, this is probably due to the relatively small cross-country variation in the explained variable. Indeed, up to 1914 there were very little limitations to unfettered capital movements between nations, while most countries converted to controlling capital flows between the wars, albeit with varying intensity. Contemporary empirical studies are mostly cross-section and cannot be easily transposed to an historical setting with considerably less between variation.

Nevertheless, the within variation is sufficient to identify the causes of the reversal in policies toward capital openness in the interwar period. World War I looms large in this reversal, as suggested by the speed with which this transformation occurred. Before the war there was a broad consensus across the political spectrum about the advantages of not tampering with capital mobility. Only at the far left was there an uncompromising critique of capital exports as instruments of the extension of imperialism, the 'highest stage of capitalism' (Hilferding 1920, Lenin 1916). In 1919 Maynard Keynes famously reminisced about these happier days with the image of the unsuspecting Londoner who, while sipping his morning tea in bed

adventure his wealth in the natural resources and new enterprises of any quarter of the world, and share, without exertion or even trouble, in their prospective fruits and advantages ... and would consider himself greatly aggrieved and much surprised at the least interference. ${ }^{3}$

\footnotetext{
${ }^{3}$ Keynes (1971 [1919]: 6).
} 
Only a few years later, Keynes started questioning the value of the investment of British capital abroad, eventually coming round to think that it would be better to

minimise rather than... maximise economic entanglement between nations. Ideas, knowledge, art, hospitality, travel - these are the things which should of their nature be international. But let goods be homespun whenever it is reasonably and conveniently possible; and above all let finance be primarily national. ${ }^{4}$

Not ignoring the role of the war in accelerating this transformation, some authors speculate that even in a counterfactual world with no war, the anti-globalisation political coalition would have gained enough clout to reverse the process anyway (O'Rourke and Williamson 1999; Daudin, Morys and O'Rourke 2010).

In order to understand these arguments, the paper is organised in three parts. We start by reviewing the available evidence on the degree of international financial integration up to World War II. This section will set the stylised facts to be explained by theory and tested in empirical models and historical narratives. The second part then introduces the main theoretical arguments behind capital controls and financial repression. These divide in two groups: second-best and political economy. In secondbest arguments, the presence of other distortions or externalities makes capital integration sub-optimal such that restrictions on the flow of capital across borders can be welfare-enhancing. The reverse might also be true, as network externalities make the value to a country of opening up to foreign finance an increasing function of the number of other countries also open. This is not the arena of political economy arguments, where interest groups with opposite net gains from capital openness compete for political power in order to enact their most preferred policy. The final part of the paper assesses the ability of the several theories of capital controls and financial repression to explain the history of global financial liberalisation.

\footnotetext{
${ }^{4}$ Keynes (1982 [1933]: 236).
} 


\section{What is there to explain?}

This section will set the stage for the remainder of the paper by defining a working concept of financial liberalisation and discussing the available quantitative indicators of trends in capital openness. A way of thinking about international financial liberalisation is to identify it with the absence of regulatory constraints on crossborders capital flows in three situations: payments for foreign goods and services and service of foreign debt (current account liberalisation); new investments into and out of a country (capital account liberalisation); and absence of discrimination against particular transactions or partners through multiple exchange systems (unification of the exchange rate). In the rest of the paper we will refer interchangeably to international financial liberalisation or capital openness and to financial repression or capital controls as their contrary. Although relatively straightforward, this concept is hard to operationalise because all the accessible empirical counterparts are flawed in some way or another.

A first distinction divides de jure from de facto measures. De jure indicators are aggregated from lists of regulatory restrictions to different types of capital transactions. The most popular of these indices is due to Quinn (1997), which is available since 1950 and codes not only the presence but also the intensity of controls on current and capital account transactions. Among the problems with these measures are the need to aggregate partly judgemental assessments of policy restrictions on disparate types of capital flows, and their incapacity to capture the degree of enforcement of existing regulations. The alternative is to use the evidence on actual flows to measure capital market integration. These de facto measures raise the complementary of overstating the degree of capital controls, as cross-border flows depend on a number of factors unrelated to actual policy intent - economic and political circumstances (domestic and abroad), differential risk and liquidity, legal barriers, home bias, and so on. De facto measures come in two flavours - price and quantity. Price measures attempt to assess financial integration from price differentials in financial assets across space. Interest parity conditions are popular proxies in this context. Quantity measures, on the other hand, focus on the size of flows or stocks of foreign assets normalised by the size of the world economy. Rather than just measuring these quantities, other authors have proposed to use the correlation between domestic savings and investment as a measure of financial integration (Feldstein and Horioka 1980). In well integrated countries, investment will not be constrained by domestic savings, as they are able to tap into the pool of international capital; so that this correlation should decrease with financial liberalisation.

A second limitation, in historical research, is data availability. Although capital markets are among the more prolific sources of data in history, we still don't have a comparable abundance of data relative to researchers on contemporary financial integration. As regards de jure measures, Quinn (2003) extended his index to the 
period 1890-1931. Figure 1 depicts the time series of the average value of this index for three groups of countries.

Figure 1: Average Capital Account Openness, 1890-2004

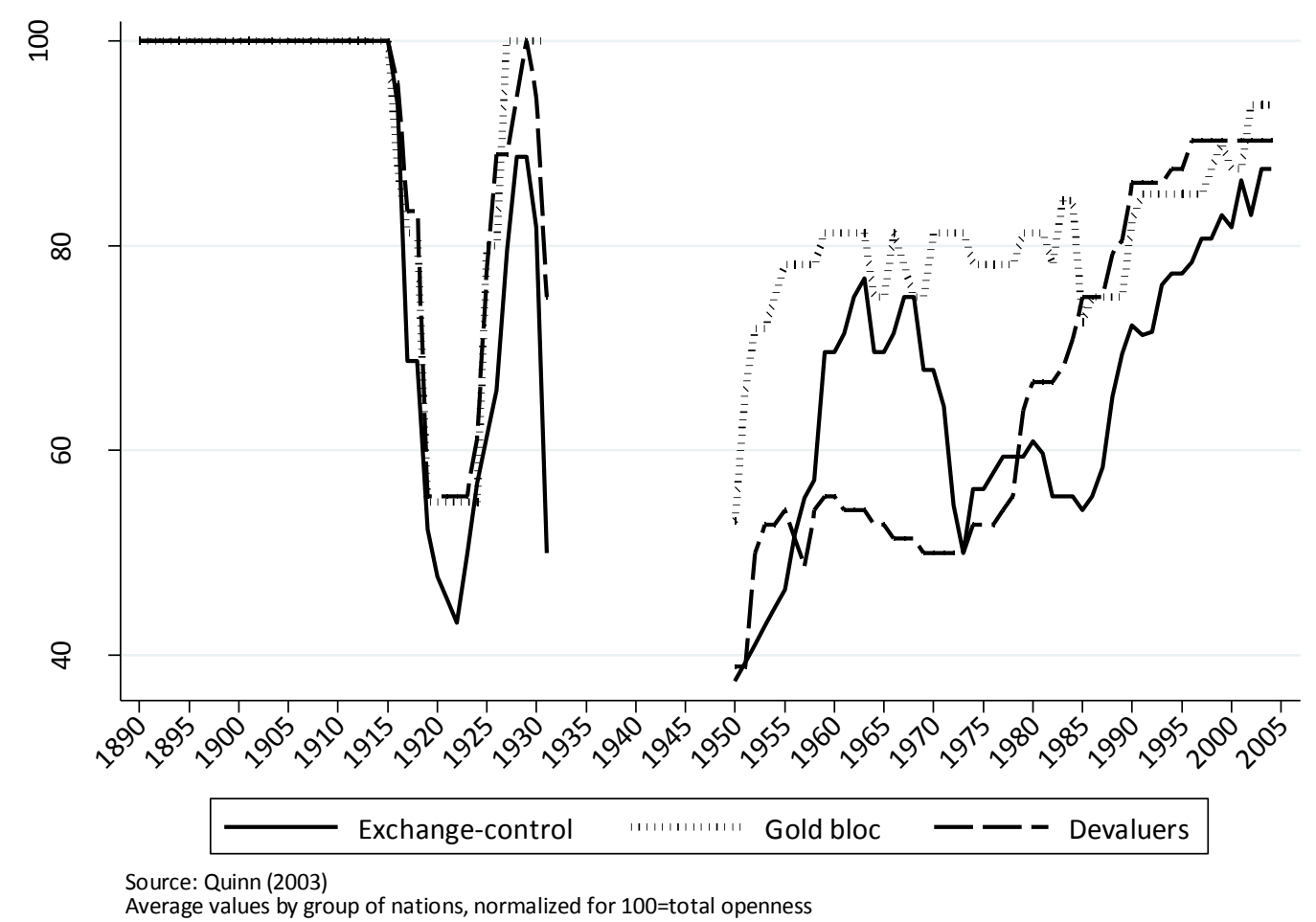

The overall story in this picture can be described in three stages. Financial integration was highest prior to World War I (a 100 value means full capital openness), with hardly any variation across nations; the War put a stop to this state of affairs, despite some attempt at reintegration in line with the re-establishment of the gold standard until 1928. However, the Great Depression elicited an even more autarkic reaction from most countries. Substantial variation across groups of nations also emerged in this period. A 1938 study from the League of Nations classified countries in three groups according to their exchange rate policy since the demise of gold in the 1930s: 'gold bloc' countries that persisted in their pegs to gold until the second half of the decade; 'devaluers' that more quickly dropped their pegs and allowed their currencies to devalue; and 'exchange-control' nations that kept their pegs but only through imposing very severe exchange and capital controls. ${ }^{5}$ This ordering is reflected in the average indices of capital openness for the three groups of countries up to 1931, with 'devaluers' restricting financial openness less than 'exchange-control' nations. Relative capital market restrictions persisted throughout the Bretton Woods period, and were only reversed since the late 1960s. Interestingly, there is persistence in attitudes toward capital controls among groups of nations. The previous members of the gold bloc were the first to liberalise after the war and mostly persisted on that

\footnotetext{
${ }^{5}$ See Obstfeld and Taylor (2004) for details.
} 
track since, while 'exchange-control' quickly reverted to greater capital restrictions after the collapse of the Bretton Woods system in 1971. On a de jure basis, capital mobility is censed to remain below the pre-1914 levels even today.

Even if incomplete, this summary rhymes with the evidence on actual capital flows and price convergence. Price measures unanimously confirm the trend of increasing integration until the war, then drastically reversed and later recovered. FeldsteinHorioka coefficients are less supportive of a monotonous trend of increasing integration until 1914, but that has been put to deficiencies of the concept itself (incapable of distinguishing integration from risk and liquidity, for instance) and to sensitivity of the results to the choice of the sample of nations. ${ }^{6}$ Figure 2 depicts the size of the foreign capital stock owned by a sample of the seven largest capitalexporting nations since the nineteenth century, normalised by the world GDP or the GDP of these nations.

Figure 2: Foreign Capital Stocks, 1870-2000

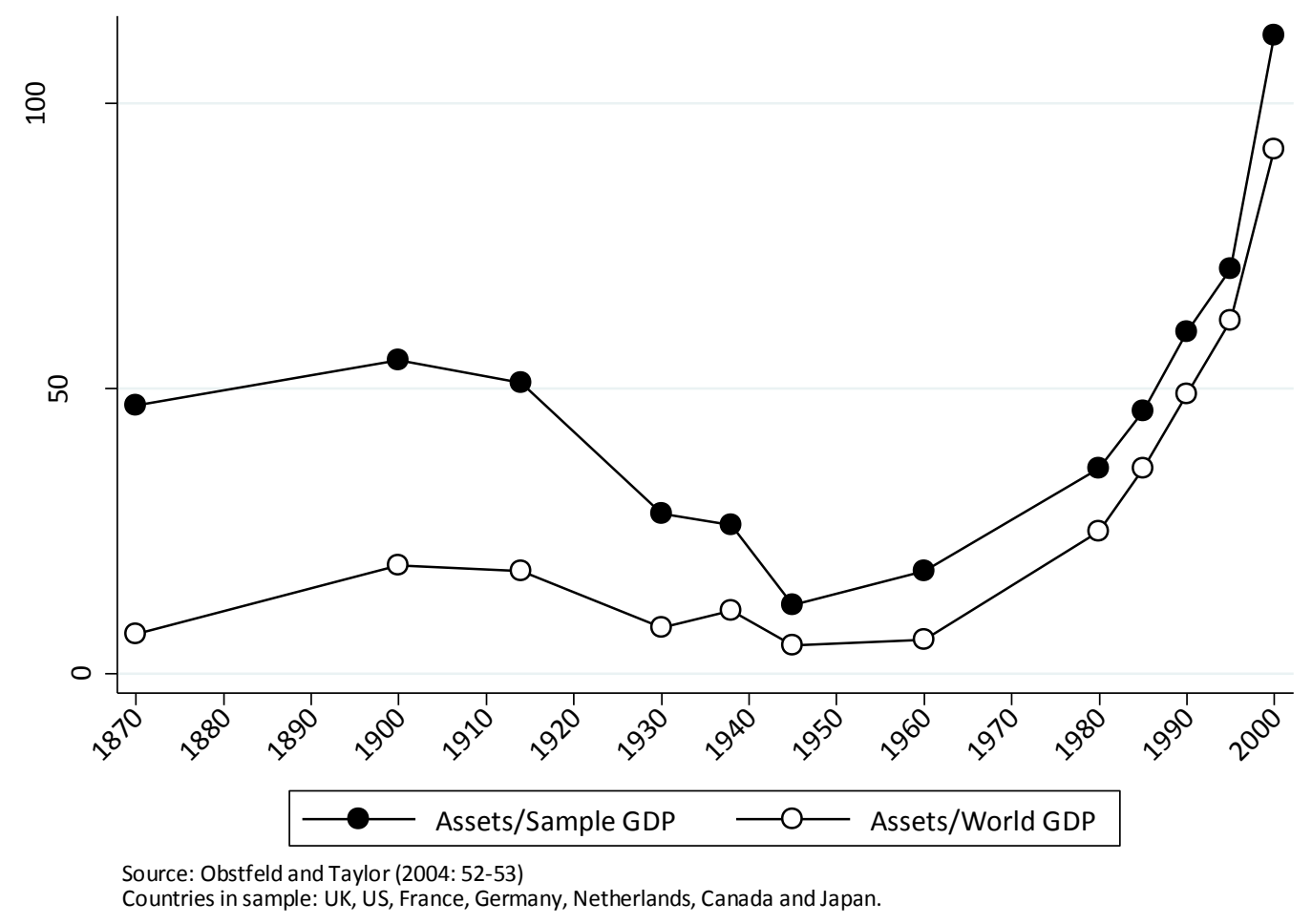

The 'great reversal' in the interwar, which was also reflected in Figure 1, is the main challenge for a political economy explanation of international financial liberalisation in history. We start to build such an explanation in the following section by reviewing the main theoretical arguments for restrictions to financial openness.

${ }^{6}$ See Obstfeld and Taylor (2004) for a review. 


\section{Theory}

As already mentioned, theoretical arguments for capital controls come in two guises second-best and political economy arguments. In both cases, however, it is important to distinguish the position of capital exporting and capital importing nations. Even though it is tempting to follow an international trade analogy, where the consequences of openness are complementary between pairs of trading nations, there are considerations which are specific to just one type of countries - particularly in political economy models.

\subsection{Second-best arguments}

The theory of the second-best sustains that removing a distortion to the operation of markets may not be welfare enhancing when there are other distortions. In these cases it is socially preferable to maintain a certain level of 'optimal' distortions. The application of the theory to international capital movements and financial liberalisation is straightforward (Bhagwati and Brecher 1980, Stiglitz 2000). The classical distortions identified in financial markets are driven by information asymmetries about the quality of borrowers (adverse selection) or their actions (moral hazard). Under adverse selection, investors are not able to distinguish the creditworthiness of potential projects, and consequently will only be willing to pay a price for a given security up to the expected quality of firms issuing securities. Because this price will be below the fair value of good projects and above that of bad (or riskier) ones, the riskier borrowers will have a greater incentive to apply for external finance. By contrast, many good projects with positive net present value will go unfunded and untried as good firms will issue fewer securities than optimal. In this setting, a liberalised capital market does not yield an efficient allocation of funds.

Borrowers can also explore their informational advantage strategically by changing their behaviour, after receiving outside financing, in a way that increases the upside but also the downside risk of their projects. Under limited liability, creditors will share only partly in the upside (or not at all, in the case of debt contracts) and will have to bear the full downside cost. In anticipation of this, investors will ration funds to suboptimal levels, a problem that cannot be solved simply by liberalizing capital markets. Providing insurance for domestic investment is also not a solution inasmuch as government guarantees to particular firms or sectors can lead to excessive capital inflows into those ventures and a serious misallocation of funds (McKinnon and Pill 1997). ${ }^{7}$

Apart from these fundamental informational asymmetries, there are other candidates in the literature for externalities advising the restriction of capital flows. It

\footnotetext{
${ }^{7}$ This line of argument was used by several authors in connection with the 1997 East Asian financial crisis, partly blamed on the domestic misallocation of funds (domestic and foreign) through practices of “connected lending” (Radelet and Sachs 1998, Charumilind et al. 2006).
} 
is easier to discuss them by separating capital-exporting from capital-importing nations. Starting with the former, domestically-installed capital may generate positive externalities, in which case the social rate of return to investment will be above the private rate. Open capital markets, however, only ensure that domestic returns equal the world interest rate (the opportunity cost of capital). A natural solution to overcome this wedge and encourage more domestic investment is to tax or otherwise restrict capital exports (Claasen 1985). However, it is not clear what sort of externalities might be involved here, at least in a static model of resource allocation. Not so in a dynamic setting with increasing returns, such as models of "infant industry" or "big push" industrialisation, where an initial advantage in capital accumulation perpetuates itself through productivity gains (Murphy, Shleifer and Vishny 1989). Other models emphasise the possibility of negative externalities, mostly borrowed from international trade theory. ${ }^{8}$ If a country is big enough to influence the world cost of capital then it may be welfare-enhancing for it to restrict capital exports. Although it will lose some return from less investment abroad, by reducing the supply of capital it will raise the world interest rate and hence earnings per unit of capital exported. This can be accomplished by the choice of an optimal tax on capital and is a straightforward extension of strategic trade theory (MacDougall 1960, Kemp 1966). ${ }^{9}$

Another extension from trade theory but applied to capital importers is the idea of immiserizing capital flows. The classical reference for this argument is Bhagwati's (1958) article, which is set in a two countries-two goods Heckscher-Ohlin model of trade. In this context, an exogenous increase of the capital stock -e.g. through opening to international finance- will lead to a more-than-proportional rise in the production of capital-intensive goods (a Rybczynski effect) and a reduction in the production of labour-intensive goods. Although specialisation in this model is driven by relative factor endowments, a country may be specialised in capital-intensive goods and still be recipient of capital imports either because of initial (pre-trade) misallocation of funds or because it combines its relative capital intensity with natural resource abundance. This extension of the model has been used to characterise the position of the US economy up to World War I (Fogel 1967). The extraction technology of American resources was very capital-intensive, which gave a comparative advantage to the US in the capital-and-resource-intensive export sector, later compounded by specific technological advances (Wright 1990). In consequence, although the US

\footnotetext{
${ }^{8}$ But not all. For instance, sovereign immunity generates the possibility of political defaults which, if not properly priced in international capital markets, may lead to excessive investment in foreign securities. In that case it would be advantageous for governments of capital surplus nations to impose a Pigouvian tax on capital exports. However, even if there is abundant evidence that markets are not good at anticipating sovereign default problems (Rogoff 1999), this argument assumes that governments are better informed than investors, which is hard to sustain.

${ }^{9}$ The reverse argument applies, in this case, to capital importing nations that can also reap a terms-oftrade gain by restricting (or taxing) capital imports.
} 
departed from a lower capital/ labour ratio, it attracted substantial foreign investment and specialised in capital-intensive exports.

The potential for a welfare loss from this pattern of specialisation comes from a price externality, i.e., deterioration in terms of trade if the country is large enough to depress the world price of capital-intensive exports relative to the increase of the price of labour-intensive imports. This result depends on specific conditions about demand and supply elasticities, which we cannot assess here. However, the whole argument rests on three assumptions unlikely to be verified in most emerging and developing nations, namely, that they are large enough to influence world prices of traded goods, that all countries have access to the same technology, and that capital-importing nations specialise in capital-intensive goods. In our period of study, the last assumption is more of an exception than the rule, in the context of the debate on 'American exceptionalism.' That capital imports are frequently a vehicle for the importation of superior technologies is also attested by many historical examples. Finally, most emerging nations have integrated in the world market as price-takers, with the exception, again, of the US, and of the new 'giants' -India and China. Johnson (1967) offers a simple variation of this argument applied to small open economies with capital-intensive import-competing sectors that are protected behind a tariff barrier. In that case, capital inflows will obviously increase even more the domestic price distortion and lead to an even greater specialisation away from the comparative advantage of the country in labour-intensive goods. This reasoning is even less convincing than Bhagwati's (1958) because it rests on a Dr Jekyll-Mr Hyde characterisation of policy authorities, which are benevolent when setting capital controls but self-interested when fixing inefficient tariffs. It is also closer to a political economy framework, which will be discussed later.

Openness to foreign capital has costs in terms of constraining the ability to pursue independent stabilisation policy in the usual Mundell-Fleming way, particularly if domestic authorities are not credible (Mathieson and Rojas-Suarez 1994). Likewise, in a world where financial markets adjust faster than the real sector (Dornbusch 1976), capital controls may help with reducing excessive exchange rate volatility driven by short-term capital flows. It will be noticed, though, that both arguments only provide a justification for temporary controls. A more significant indictment against openness to capital imports is its alleged relation with enhanced financial volatility and, particularly, crises. This is not the place to review the very extensive theoretical and empirical literature on the subject, but it suffices to emphasise the main points of the debate. ${ }^{10}$

A fundamental divide in the theory of financial crises separates so-called first and second-generation models. In first generation models, countries bring crises on themselves through bad fundamentals and bad policies (Krugman 1978, Flood and

\footnotetext{
${ }^{10}$ For extensive reviews of the literature, see Calomiris (2005), Eichengreen (2004) and Henry (2007), among many.
} 
Garber 1984). Second-generation explanations are based in multiple-equilibria or 'sunspot' models (Obstfeld 1986). At the core of these models are the informational asymmetries mentioned at the beginning of this section, which can lead to herd behaviour, contagion, and other capital markets imperfections (Obstfeld 1996, Krugman 1996). For instance, by increasing the menu of assets available to investors and by promoting portfolio diversification, financial globalisation reduces the incentive to acquire information on individual assets aggravating the incomplete information problems (Calvo and Mendonza 2000).

Despite attempts at reconciling the two perspectives (Jeanne 2000, Morris and Shin 1998), blaming crises on capital openness makes most sense in the context of secondgeneration explanations. ${ }^{11}$ Are capital controls an improvement in these models? A positive answer depends on two premises: that capital openness does make economies more vulnerable to financial crises or, at least, that it increases the real costs of such crises; and that these costs are not outweighed by the access to superior growth possibilities. The fact that different models have contrasting predictions about the relation between financial openness and crises has comprehensively led to an empirical focus in the literature in order to try and establish causality. Unfortunately, there is not much agreement among the extensive list of empirical papers on this subject. This has partly to do with empirical problems in the literature, namely, the pervasive endogeneity in the relation between openness and crises, both from the side of nations considering which policy to adopt, and from the side of foreign investors having to decide whether to liquidate their investments in a given country. According to Martell and Stulz (2003), financial liberalisations can be seen as the equivalent of countrywide IPOs. Like firms, countries have an incentive to be strategic about choosing the moment to liberalise, i.e., when the market prices for its securities are high -either because of exceptional growth opportunities, or because they are overvalued. As for foreign investors, "like an infectious disease, they are likely to pick off the weak, not the strong. But as with any plague, even robust health is no guarantee of survival" (Eichengreen 2004: 294). A corollary of the uncertainty of these results is the equally ambiguous conclusions on the ability of capital controls to prevent crises. Causality here can also run both ways: on the one hand, controls are more used by countries with severe macroeconomic imbalances, on the other, the extra degree of autonomy afforded by capital controls might tempt them into more expansionist policies, resulting in greater imbalances. A variation along these lines is to attempt to identify the source of bad policies. Acemoglu et al. (2003) do so by exploring an exogenous source of variation in domestic political institutions to conclude that macro policies are not a direct cause of excess volatility. They show empirically that weak institutions work through macroeconomic policies to affect economic outcomes, such as excess volatility.

\footnotetext{
11 See, however, Rogoff's (1999) negative assessment of the market's ability to anticipate the consequences of deteriorating fundamentals until it is too late to avoid a crisis.
} 
The second premise, that the costs of volatility prevail over the benefits of access to external finance, is associated with another extensive body of literature that studies the relation between finance and growth. ${ }^{12}$ Empirical studies of this relation have also been mostly inconclusive, although there has been considerable progress at identifying the origin of the disagreements. These are driven not only by empirical methodology, but also by different theories of growth. As pointed out by Gourinchas and Jeanne (2006), the long-term gains of financial integration are likely to be very small in the context of a Solow growth model with constant returns to scale. Even though the access to foreign finance allows for a substantial acceleration in the rate of capital accumulation, this will only be a transitory effect, with no impact on the long term growth rate. It is therefore unsurprising that cross-section studies cannot identify a robust relation between average growth rates and average levels of financial openness (Henry 2007). However, a different growth model can lead to completely different predictions. In endogenous growth models with increasing returns, access to foreign finance brings about permanently higher growth rates, especially if foreign capital is a vehicle for superior technology. Other authors go further in stating that the main gains from capital openness are not to be found in the traditional static or temporary mechanisms (better allocation of funds, faster capital deepening), but in deeper 'collateral' benefits that act through the importation of better governance standards, domestic financial development, and the guarantee of more sound macro policies under the Damocles sword of market sentiment (Kose et al. 2006). The problem with testing this interpretation lies, of course, in the fact that these very 'collateral' benefits are endogenous to the choice to liberalise capital flows in the first place. For instance, there is extensive evidence that openness to foreign capital in the absence of developed local financial markets leads more often than not to financial crises through excessive exposure to currency and maturity mismatches (Eichengreen 2004). And this is true even if more foreign finance acts to promote the development of local financial markets and institutions. ${ }^{13}$

In any case, higher volatility and higher growth have to be assessed in terms of welfare, as it may be the case that financially open economies are akin to high-yield equities with an ex post return that compensates investors for their higher risk. Rancière et al. (2008) pursue this analogy directly in the context of a model where, in the absence of financial liberalisation, contract enforceability problems generate borrowing constraints and lower growth. Countries with access to foreign capital can increase their growth rates by leveraging their economy through the intermediation of the international capital market. This then encourages emerging economies to take too much systemic risk that leads to severe, but infrequent, financial crises, during which these countries benefit from systemic bailouts. We will have more to say later about the appropriateness of this model to describe capital flows in history, but the

\footnotetext{
${ }^{12}$ See Levine (2005), and Henry (2007) for extensive surveys.

${ }^{13}$ See Kose et al. 2009) for an attempt to test this thesis by using instrumental variables.
} 
contribution of this paper lies in stressing the fact that some volatility may be a price worth paying for higher growth.

\subsection{Political economy}

In political economy models, capital controls are introduced to shift resources in favour of interest groups or electoral majorities holding power; the outcomes of these policies are not welfare-enhancing and frequently sacrifice total welfare to the greater gain of the beneficiaries. In sifting through another extensive literature, it is useful to borrow the distinction between 'partisan price effects' and 'macro policy effects' from Quinn and Inclán (1997).

Partisan price effects are an extension of the Stolper-Samuelson theorem to the distributional consequences of international financial integration. Similarly to trade, financial flows will affect relative input prices as these converge to international standards. This provides a motivation for individuals whose incomes are depressed by liberalisation to support financial repression. The identity of anti-liberalisation groups is dependent on the structure of the economy as well as its size. Macro policy effects have a similar distributional motivation, but do not interact with the structure of the economy; they are instead associated with the distribution of the costs and benefits of government policy between different groups of agents. Before delving into these models, we should clarify that we will be abstracting from the exact nature of the polity that generates the political outcomes. This is clearly not because the exact nature of constitutional rules is secondary to the economic incentives of political agents, but because we want to simplify the discussion. We will consequently assume that polities cannot prevent permanently the expression of the economic interest of dominant groups. ${ }^{14}$ The relevant groups, of course, are only those enfranchised by the polity, so we will briefly mention the relation between democracy and financial integration.

A common setting in many of these models assumes an economy divided into two groups -'workers' (or 'peasants') and 'capitalists'-, which are represented, in electoral systems, by 'left' and 'right' parties, respectively. The position of these two groups in relation to financial liberalisation depends on their endowments. In a twofactor Heckscher-Ohlin world (capital and labour), the owners of the abundant input will support liberalisation, whereas the owners of the scarce input will oppose it. For instance, in nations with unskilled labour as their relative factor advantage, workers or leftwing parties will support financial integration (as wages are to increase relative to rents), whereas rightwing parties will opposite it ceteris paribus. The argument can be extended to a specific-factors model (Ricardo/ Viner), where the brunt of the adjustment to price changes is borne by owners of factors specific to particular uses, while non-specific factors are easily redeployed and face no windfall profits or

\footnotetext{
14 Schulze (2000) argues that, in the impossibility of accounting for all types of institutional environments and political regimes, the median voter model is a good enough approximation.
} 
surprise losses. Hence, pressure for or against financial liberalisation depends on the specificity of relevant agents' assets, and political cleavages will be sectoral rather than factoral. Finally, in trade models with agglomeration and scale economies (Krugman/ Venables), initial competitive advantages are reinforced by access to international transactions. Consequently, larger firms or firms with access to better networks of customers, suppliers and information are better prepared to take advantage of openness and to resist international competition. Smaller, more localised firms have an incentive to oppose liberalisation. Rajan and Zingales (2003) refine this result in a model that is richer in the specification of the financial sector of the economy. Prior to liberalisation, arms-length capital markets are inexistent or underdeveloped, so that domestic credit is mediated through relationship banking relations between financiers and firms. In the absence of good disclosure and enforcement rules, financial contracts are monitored through the connections between banks and firms and enforced by the monopoly of credit kept by the banking sector. In such settings, both industrial and financial incumbents earn positional rents from the absence of competition and have a vested interest in blocking trade openness and financial liberalisation, respectively. Given their privileged access to domestic finance (through its contacts with the banking sector), larger firms stand less to gain from financial openness, in apparent contradiction of the models of scale economies. However, there is a complementary relation between trade and capital openness, as once both are present, both incumbents have an incentive to support them. Industrial incumbents will do so because they will only be able to survive competition by investing more, for which they need access to a larger pool of finance. Financiers will want to expand their clientele (once relationship-based credit is competed away), and as new clients will be less well-known (and possibly riskier), they will also press for better disclosure and impartial enforcement.

There are several candidates for macro policy effects in the literature. One of the earliest contributions is from Alesina et al. (1989), who model an economy where capitalists and workers compete for the distribution of the burden of taxation. Both groups can smooth their consumption paths by borrowing from abroad (capital imports) or investing in foreign assets (capital exports). In this context capital controls are never imposed by rightwing governments (which favour capitalists) because they would impose a binding constraint on capitalists' optimisation problem. From the perspective of leftwing governments, controls have the attraction of forcing capitalists to invest domestically. Unlike foreign investments, domestic capital can be taxed and the proceeds redistributed to workers. Domestic investment also creates jobs locally, which are more valuable to workers. However, if workers are sufficiently risk averse, capital controls will also constrain their smoothing decisions, and leftwing governments will be less likely to impose them. This framework can be readily extended to other types of taxation, such as the inflation tax or financial repression to reduce the cost of government financing requirements. Capital controls are necessary in the first case to prevent inflation tax avoidance via currency substitution, whereas the compression of domestic interest rates in the second (to below world levels), to 
help finance government debt, is equivalent to a tax on foreign assets. ${ }^{15}$ Countries with independent central banks will therefore be less likely to impose capital controls for these revenue motives.

Rent-seeking can be construed as another form of redistribution motive for capital controls, inasmuch as the imposition of controls vests additional power with bureaucrats, creating incentives for corruption (Dreher and Siemers 2009). Other than just to retain domestic savings, capital controls may also be imposed for nationalistic reasons, namely, to limit the foreign ownership and control of domestic assets. This argument would be particularly relevant for small open economies. In a world with few financial frictions, the Capital Asset Pricing Model (CAPM) implies that all investors would be fully diversified by holding a similar portfolio of world's securities, weighted according to the market cap of each asset (Goetzmann 2004). The investors in small open economies would then hold most of their portfolios in foreign assets, while their own capital stock would be owned by foreigners, with no personal stake in the impact of their investments in the local economy and society. This conflict between the logics of stakeholders and investors can also be seen in relation to the size of the public sector and, in particular, the redistributive functions of the government. The causality, however, is not clear, since countries with large public sectors may be afraid of a 'race to the bottom' of capital taxation, imposed by the mobility of capital (Rogoff 1997). But there is also evidence that a prior social protection net may help with garnering support for capital openness, because it operates as a credible compensation for individuals or groups who stand to lose from globalisation (Garrett 2001, Quinn 1997).

Another way of looking at the relation between capital controls and macro policy is through the lens of the 'policy trilemma,' as summarised by Obstfeld and Taylor (2004). The authors use a simple incompatibility framework -between fixed exchange rates, open capital markets, and monetary policy autonomy- to organise two centuries of macro history. Pre-1914 nations overwhelmingly preferred to sacrifice policy autonomy to the other vertices of the unholy triangle; the interwar period saw those preferences reversed in favour of regaining independence (at the cost of exchange rate stability); whereas the postwar period reverted to exchange rate stability but with less capital mobility, during the Bretton Woods period, and to a stance similar to the interwar equilibrium after the demise of this international monetary system. This is, of course, a very aggregate description that masks a considerable variation among groups of countries (particularly emerging versus developed). ${ }^{16}$ It is also mostly useful in identifying the constraints of policy rather than at predicting policy choices. For instance, it doesn't predict under what circumstances countries will prefer, say,

\footnotetext{
${ }^{15}$ The two instruments can also be complementary via portfolio composition effects, since with higher inflation agents will hold less money and more government bonds (and vice-versa).

${ }^{16}$ For an attempt at characterizing individual countries' choices in the context of the trilemma in the post-Bretton Woods period see Aizenman et al. (2008).
} 
capital openness and a fixed exchange rate -as most nations did before 1914-, or capital controls and a fixed peg, like many emerging economies since the 1970s.

Having ignored so far how the nature of political institutions interacts with policy preferences of domestic agents, we would now like to mention the literature on the relation between globalisation and democracy or the extension of the franchise. Here again it is not easy to reach a consensus. A political regime that attunes politicians to broad social interests (as opposed to those of installed interest groups) or lengthens their horizons (trumping short-run political calculation) will make it more likely that policymakers internalise the benefits of financial integration. Hence, democracies would be more likely to liberalise, except, of course, if the majority of the population (or the median voter) stands to lose from the move. However, a democracy is a mechanism to solve social conflicts (about taxation) that would otherwise require the resort to inefficient solutions such as financial repression and the inflation tax. From this viewpoint, capital controls would be less valuable for policymakers in democratic countries. Moreover, if incumbents oppose liberalisation for the sake of their protected rents, greater domestic political and economic competition will dilute those rents and make them less averse to integration (Rajan and Zingales 2003). Finally, Eichengreen and Leblang (2008) raise the important point that the direction between democracy and globalisation may be bidirectional. Not only are democracies better at having policymakers internalise the benefits of integration in the world markets, but the freedom of circulation of goods, capital, labour, and ideas can also affect the nature of the political regime. Just to take two examples, the globalisation of ideas is likely to encourage political competition, while financial market integration requires discipline and transparency of governments, undermining autocratic regimes. With a positive two-way relation, the question arises whether the system is dynamically stable or not. The future of democracy and globalisation can depend on this property of the system. Faced with a negative shock to integration (tariffs, capital controls) or to democracy, a stable system will converge to a new equilibrium with lower levels of both variables. An unstable system, on the other hand, will diverge without obvious bounds to lower and lower levels of openness and democracy. Forcing the argument a bit by 'looking to the future from the past,' one could say that the evolution of the world economy and polity in the 1930s seems to fit with a dynamic unstable system at the time.

To conclude this section, we want to refer to the possibility of 'policy contagion' from other countries conditioning the domestic policy stance. Contagion can happen through several ways -competition, emulation, learning, external pressure, or just ideological sympathy. In a sense, this literature characterises another type of externalities that can make capital openness constrained-optimal. Capital market integration may be conceived as a case of strategic complements through network externalities, as the worth to a given country of opening up its capital market increases with the number of other nations already integrated. On the contrary, emerging economies may perceive liberalisation as a strategic substitute, if they have 
to compete with other nations for foreign finance by deregulating their capital markets for foreign investors. In both cases, we cannot explain a country's decision to liberalise purely from domestic political economy considerations. Countries may also be influenced in less direct ways, e.g. by picking up policies that appear successful in other nations (learning) or that have been adopted by ideologically close regimes (emulation). Recent empirical evidence on the contemporary process of financial integration lends particular support to competition and learning as drivers of policy contagion. $^{17}$

\footnotetext{
${ }^{17}$ See Brune et al. (2001), Simmons and Elkins (2004), and Quinn and Toyoda (2007). By contrast, these studies have not found support for the dependency hypothesis that liberalisation has been imposed on emerging economies by the core of advanced nations, either directly, or through the intermediation of multilaterals (IMF, World Bank).
} 


\section{History}

Having gone through the main theoretical arguments for the existence of restrictions on cross-border capital flows, we now turn to the historical evidence to try and make sense of the patterns of financial liberalisation described in section 2. Consequently, this section will be mostly devoted to empirical literature on the causes of the rise of the first wave of globalisation and of its demise in the interwar. In fact, the political economy of trade and migration policies or of exchange rate regimes is much better studied than that of capital controls, particularly for the prewar period. As previously mentioned, this is probably due to the fact that capital flowed mostly unfettered across all types of countries before 1914. World War I therefore provides a natural breakpoint in this section. We try to use the within variation across the two periods to explain both the absence of obstructions to capital flows before the war and their emergence after 1914.

\subsection{Prewar}

The salient fact to explain before 1914 is the almost complete absence of fetters to the free circulation of capital worldwide. The attachment to this vertex of the 'trilemma' was consistent and common to all sorts of countries: capital-exporting, as well as capital-importing, developed as emerging, within as outside the gold standard (the fixed peg of the time par excellence); and across different economic structures and political regimes. It is also symptomatic that the first time countries tried to combine exchange rate stability (by pegging to gold) with capital controls was in the context of the 1930s, following the lead of Hjalmar Schacht, the energetic president of the Reichsbank (James 2001).

The only examples of distortions to capital flows in this period come from capital exporting nations, but were moderate in impact or motivated by considerations other than those discussed up to now. The major European powers discriminated in favour of their colonies and protectorates by conceding an explicit guarantee to government securities issued by them in their markets. Such was the routine practice of France, Germany, and also of the UK, which institutionalised the practice through a series of Colonial Stock Acts between 1877 and 1900. Another form of distortion, this time negative, was the taxation of the investment (stamp) and income of foreign securities. Most countries charged higher rates on foreign than domestic securities, but these duties were still very modest. ${ }^{18}$ Besides, in the absence of other restrictions to capital movements, contemporaries frequently explored differences in taxation by domiciling

\footnotetext{
${ }^{18}$ For instance, at the end of the period, France charged $2 \%$ stamp on foreign private securities, against $1.2 \%$ on domestic ones; and $1 \%$ on foreign government bonds, while the bonds of French and colonial governments were exempt. The coupons of the latter were also exempt from income tax, but not the coupons and dividends of foreign issuers that paid $4 \%$. The German tax law only discriminated against foreign governments, which had to pay $1 \%$ stamp and $0.2 \%$ income tax, while internal sovereign issues were exempted. British taxes did not discriminate between domestic and foreign securities.
} 
their portfolios in jurisdictions with lower taxes. Other negative measures were directed more at controlling the distribution rather than the volume of capital exports. Much has been written about the political underpinnings of European capital exports and their connections to diplomatic and imperialistic ambitions of the great powers. ${ }^{19}$ Some countries outwardly claimed to control the nature of the investments of their nationals abroad. France was the most obvious case, in that the flotation of foreign securities in French stock exchanges was dependent on the authorisation of the finance minister, who used it regularly to discriminate against German issues after $1871{ }^{20}$ Similar, if less institutionalised, means were used in other countries, such as Germany, to favour allied governments. ${ }^{21}$ In any case, all these measures were taken with a view to acquiring political advantages abroad, which are not necessarily connected with the economic advantages of political agents or the economic structure of these nations. Furthermore, domestic investors were not constrained by the political preferences of their governments in building up their portfolios, as the almost complete absence of barriers to capital circulation and the increasing interconnectedness of the European banks and exchanges allowed them to invest in securities traded in any country. ${ }^{22}$

The main capital-exporting nations were also the only ones where a debate ensued on the advantages of free international capital flows. The arguments of the opponents to capital exports closely trailed what we referred to as second-best arguments for capital controls. Capital exports were condemned for crowding out the domestic industry (or even governments) from the market, or for the excessive risk involved in 'exotic' securities, on which no reliable information was available and against which domestic investors had little protection because of differences in jurisdiction and sovereign immunity. In the UK, the debate took on class overtones in the historical literature, with opponents of capital exports blaming the 'negative home bias' of the City on a particular type of 'gentlemanly capitalism,' brought about by income inequality and benefiting from the government's deferential treatment of financial and banking interests (Cain and Hopkins 1980, Rubinstein 1987). These biases would have been responsible for the slowdown of the British economy during its late Victorian and Edwardian 'decline,' relative to the fast advances of Germany and the US in the new technologies of the Second Industrial Revolution. This debate is today mostly resolved against the initial hypotheses. The implied macroeconomic

\footnotetext{
${ }^{19}$ See, among many, Hobson (1902), Feis (1930), Fishlow (1985), Davis and Huttenback (1986); Lévy-Leboyer (1977), Lévy-Leboyer and Bourguignon (1985), Marseille (1984); Hilferding (1920), Lenin (1916), and Barth (1995).

${ }^{20}$ But apparently without much success, as shown by Flandreau and Gallice (2005).

${ }^{21}$ Such as Turkey or Austria-Hungary. Another example of outward discrimination was the Lombardverbot of 1894, whereby Russian securities stopped being accepted at the discount window of the Reichsbank.

${ }^{22}$ Contemporaries frequently mentioned the active 'arbitrage' in foreign securities between the main European financial centres. See Esteves (2007) for discussion.
} 
counterfactual of lower cost of capital and higher investment has been questioned given the structure of British industry at the time, which still enjoyed the agglomeration advantages of the export sectors of the First Industrial Revolution, while lacking some of the requirements to take on the technologies of the Second particularly a qualified workforce (McCloskey 1970, Edelstein 1994). ${ }^{23}$ Recent research has also shown that the pattern of investment in foreign securities not only did not result in lower returns ex post, but also allowed British investors to reap the benefits of portfolio diversification (Edelstein 1982, Goetzmann and Ukhov 2006, Chabot and Kurz 2010). ${ }^{24}$ Finally, the simple model of political allegiances of "gentlemanly capitalism" has also been put into question (Daunton 1989, Porter 1990). In this model, which closely trails the factoral cleavage of an Heckscher-Ohlin trade pattern, City capitalists (the owners of the abundant factor) have a clear incentive to support capital openness, whereas workers (or industrialists) and landowners should oppose it. Recent accounts uncovered a more nuanced situation, where there was no concerted industrial-agricultural coalition against capital exports, domestic industry was able to finance itself mostly out of retained earnings, and even the labour movement did not oppose the freedom of capital flows, in the context of a worldview of peace, democracy and progress (Trentmann 1997). There was, to be sure, considerable ideological variation within the labour movement, particularly at the far left, which more or less converted to the Marxian interpretation of capital export as 'rentier's dream' at the cost of domestic unemployment. Nevertheless, the majority of the organised labour movement joined liberal parties in opposing restrictions to factor flows, even if they supported higher tariffs on trade. ${ }^{25}$ Other authors have preferred to attribute the absence of labour antagonism toward globalisation in this period to the limited franchise in place in most prewar nations, or to make a specific political economy argument for this lack of opposition. The relative weakness of the organised labour movement, especially as a political force before World War I -with the possible exception of Germany- would have isolated policy authorities from domestic political pressure and allowed a credible commitment to the gold peg and capital openness (Eichengreen 1992). Daunton (2006) disputes this rendering of facts, as far as the UK is concerned, claiming instead that this policy stance attracted widespread support among organised labour as it delivered rising real wages.

Moreover, optimistic contemporaries were convinced that there was a positive feedback from capital exports to the demand for exportables. In the words of the National-Zeitung:

\footnotetext{
${ }^{23}$ For an interesting dissenting opinion, see Temin (1987).

${ }^{24}$ For similar conclusions on French foreign investment, see Parent and Rault (2004); and on Germany Müller (1992) and Schaefer (1993).

${ }^{25}$ Lenin (1916) accused the 'aristocracy' of English labour of opportunistically supporting colonial Imperialism and capital export.
} 
Foreign countries can only be buyers of our products if that amount which is not compensated for by their exports, they can cover through debt. To ban this, out of anxiety for the capital of the German worker, who works for export, is in fact to take his job away. ${ }^{26}$

There are plenty of anecdotes about this feedback, especially in railway construction, which was financed with European money and equipped with European rail stock. However, more recent research has reversed the direction of causality in this relation and emphasised conditions in capital-importing nations as driving financial flows. This literature focuses on the relations between the hegemonic nations (Britain before 1914 , the US thereafter) and the rest of the world, which may or may not be representative of other capital-exporting countries (Taylor and Wilson 2006, KalemliOzcan and Nikolsko-Rzhevskyy 2010). Nevertheless, by instrumenting trade, the authors identify a sizeable causal effect from trade flows of emerging nations with the hegemons to their access to external finance. ${ }^{27}$ The strength of this relation is explained in the context of trade models with scale economies, where trade in goods imparts informational and reputational spillovers to trade in financial assets, a point which was not lost on contemporary observers:

It is not illogical to relate the lead of England in this matter to the larger and older development of its trade, as capital export mainly arises from and is continuously increased through trade. ${ }^{28}$

What of capital-importing nations? The emerging economies of the time integrated in the international economy by specializing in the export of labour- and especially resource-intensive goods, consistent with the Heckscher-Ohlin model of trade (O'Rourke and Williamson 1999). The distributional consequences of trade provoked tariff responses in European nations and anti-migration pressures in the New World, which have been extensively explained elsewhere from political economy considerations. ${ }^{29}$ In many of these accounts international capital mobility is assumed rather than explained, freeing the authors to concentrate on the political conflict

\footnotetext{
${ }^{26}$ Edition of 7 January 1891. For reviews of this debate in Germany see Schaefer (1993) and Daunton (2006) for Britain. Lenin unsurprisingly agreed, although with a different interpretation: "The increase in exports is closely connected with the swindling operations of finance capital, which...skins the animal twice - first, it pockets the profits from the loan; then profits from the same loan when it is used by the borrower to make purchases of Krupp's goods or to obtain railway material from the steel syndicate" (Lenin 1934 [1916]: 105).

${ }^{27}$ The size of the point estimates is very different, however. Whereas Taylor and Wilson (2006) estimate an elasticity of financial flows with respect to trade of 1.2, in Kalemli-Ozcan and NikolskoRzhevskyy (2010) the equivalent coefficient is 2. Naturally, the robustness of the results depends on the quality of the instruments chosen by the authors, and so there is room for further research to clarify the magnitude of the relation.

${ }^{28}$ Steinmetz (1913: 141).

29 See Rogoswski (1989), O’Rourke and Williamson (1999), Hatton and Williamson (2005), Williamson $(2000,2006)$, and O'Rourke and Taylor (2007).
} 
between agricultural and industrial interest groups with respect to tariff policy. But it is not hard to build up a similar case for these countries' openness to foreign finance. In so doing it is useful to distinguish between two groups of emerging nations. On the one hand, there were the nations along the European 'periphery' (Mediterranean, Scandinavia, and Eastern Europe), characterised by substantial capital flows but labour outflows; on the other, the regions of 'recent settlement' in the Americas, South Africa, and Australasia that attracted both capital and labour. ${ }^{30}$

Focusing mostly on the pattern of British capital exports, the literature has identified capital-chasing-labour as a force alleviating the trade-offs of trade integration. The preference of British investors for regions of recent settlement, which were also the main recipients of foreign workers, mitigated the downward pressure on real wages in these regions, thereby preventing a political backlash against migration. Although reaching similar conclusions, Harley (2000) disputes the neoclassical logic of this argument that separates technology from factor movements and isolates the impact of the latter purely through price effects. In the case of the US, Harley emphasises the externalities in technology development and urbanisation in the context of a dynamic model of endogenous growth, with increasing returns to capital, despite the rising capital/labour ratio through the attraction of foreign investment. Many of these economies were also expanding their economic frontier, for which they required substantial investment in transportation and infrastructure (railways, ports, telegraphs), and it is unsurprising that European capital rushed to those sectors (Stone 1999). In countries along the European periphery, capital imports reinforced (rather than mitigated) the increasing trend of real wages, and conceivably would have brought enfranchised labour in favour of capital liberalisation for distributional consequences. European capital flowing to these countries (mostly French and German), apart from infrastructure build-up, favoured the financial sector, which might have generated opposition from financial incumbents as in Rajan and Zingales (2003). That this did not turn into restrictions on foreign investment is probably a reflection of the incipient nature of the financial sector in many of these nations, which was either incapable of opposing foreign competition or saw the access to foreign finance as an opportunity to expand their activities. More research is however required to test this hypothesis. ${ }^{31}$

Macro policy effects were certainly less of a consideration in this period especially among emerging nations. The small size of the public sectors and their very limited redistributive function arguably made the revenue sharing motives for capital controls largely irrelevant. Likewise, the loss of domestic policy autonomy was

\footnotetext{
${ }^{30}$ One could also include South and East Asia in the first group, largely on the force of the Indian and Chinese diaspora at the time.

${ }^{31}$ The classical reference on the relation between financial underdevelopment and foreign capital is Gerschenkron (1962). On the patterns of French and German capital exports see Esteves (2007, 2011), on the determinants of multinational banking Battilossi (2006), and on the impact of foreign capital on domestic financial development Esteves and Khoudour-Castéras (2011).
} 
probably not a concern, as the authorities of most emerging nations were not credible enough to sustain an independent monetary policy without generating adverse capital flows (Bordo and Flandreau 2003). Countries that could not adhere to the discipline of the gold peg with open capital markets resorted to periods of inconvertible paper currency and devaluation to adjust to macro imbalances. Nevertheless, monetary coordination brought about important benefits to emerging nations. Membership in the gold standard or in currency unions was related to greater business cycle coordination that relieved these nations from a current account constraint to their growth (Flandreau and Maurel 2005). ${ }^{32}$ Moreover, the credibility of the commitment to gold was dependent on the access to foreign capital (Calomiris 2005).

The flip-side of capital market integration was the heightened vulnerability to financial volatility of nations incapable of choosing the currency they borrowed from abroad in ('original sin') and subject to 'sudden stops' of external finance due to their own deteriorating fundamentals or 'contagion' from other similar countries (Bordo 2006; Catão 2005; Bordo, Cavallo and Meissner 2010; Kaminsky, Reinhart and Végh 2003). Furthermore, there is evidence that the credit cycle in core capital-exporting nations also had a direct impact on financial stability along the periphery, as today (Bordo 2006). A number of authors have tried comparing the frequency, nature, and real costs of financial crises across time (Bordo et al. 2001, Eichengreen and Bordo 2003, Adalet and Eichengreen 2005, Reinhart and Rogoff 2009). The main result from this literature is that the frequency and type of crises are not independent from the underlying policy regime and, hence, cannot be fully explained by the degree of financial globalisation. In particular, crises were much less frequent during the classical gold standard (before 1914) than today, despite comparable levels of financial integration. The difference is largely driven by greater numbers of currency crises today, which were limited by the operation of the gold standard before World War I. Currency collapses were also less likely back then to endanger the solvency of domestic banking sectors. Some authors see in this change the consequence of moral hazard problems created by more active lender-of-last-resort policies after the war that effectively socialised the risk of the financial sector and led to more leveraged cycles (Calomiris 2002, Schularick and Taylor 2010). ${ }^{33}$

Although less frequent, there is no evidence that crises were less severe -in lost output- in the historical period than recently. However, this in itself is not conclusive, as we have to subtract the costs of volatility from the income gains through accelerated convergence (in a Solow world) or even permanently higher growth rates, in models with investment externalities. A direct test of Rancière et al's (2008) model

\footnotetext{
${ }^{32}$ This was all the more important since trade integration had the reserve effect, because the nature of specialisation before 1914 (inter-industry) reduced the coordination of business-cycles commovements between developed and developing countries.

${ }^{33}$ For a different interpretation, linking greater financial stability during the classical gold standard to the mitigating effect of the financial flows from international migration (remittances), see Fenoaltea (1988) and Esteves and Khoudour-Castéras (2009).
} 
for the prewar period concluded that in the long-term there was a positive impact of capital inflows on per capita income, even though these flows were also related to more frequent crises and output losses in the short run (Meissner and Bordo 2007). Everything considered, emerging economies seem to 'have chosen the good part'. Nationalistic reaction against foreign ownership and control was also minor at the time, even though left ideologues saw in the ever growing expansion of cosmopolitan capital a threat to "that goal which once was the highest for the European nations: the construction of a national united state as a means to economic and cultural freedom." ${ }^{34}$ This was not a bad premonition of things to come.

\subsection{Interwar}

The impact of World War I on the global financial architecture that existed before the war was nothing short of dramatic. A liberal order of free capital and labour, relatively free trade, and exchange rate stability within the gold standard gave way to capital controls, anti-immigration laws, protectionism, and managed exchanges. Three shocks loom large in this radical transformation: the economic dislocations of the war, the rise of democracy, and the ideological threat of extreme political regimes communism and fascism.

The imperatives of the unexpectedly long and costly war forced the belligerents to actively control their domestic capital markets and the exchange rate of their currencies in order to facilitate the financing of the war effort and to control their terms-of-trade with neutral countries. The same priorities carried over to the years immediately after the war when the European economies, disrupted by the war ravages, the loss of manpower, and the need to reconvert to civil production, faced serious balance of payments problems. Once these were corrected, controls lingered on throughout the 1920s to minimise exchange rate volatility, to control speculation, or to attempt to reverse fundamental trends. Eichengreen (1992) has characterised the return to the gold standard by most countries, between 1925 and 1931, as unstable because of the lack of credibility and monetary cooperation of the system. These in turn where explained by the institutional transformations brought about by the war, above all the extension of the franchise and the greater say in national policy that the governments in conflict had promised to their populations in exchange for social peace during the war (Bürgerfriede). In this interpretation, the greater say of the working class on policy choices generated a fiscal conflict about how to pay for the war. In Britain, as in France or Germany, a political conflict opposed the left parties, who favoured capital levies, to the right, who preferred consumption taxes to retire the debt. The uncompromising attitude of the creditors (US) and of the victors (UK and France) did not help with sorting out this war of attrition and led to the continuation of the inflationary finance of the war, in the impossibility of balancing

\footnotetext{
${ }^{34}$ Hilferding (1920: 434). A substantial fraction of European capital, of course, was being invested in colonial and dependent territories.
} 
the budget. Ongoing inflation raised the real burden of debt even more and had disastrous consequences in Germany and other Central European nations. Fiscal stabilisation therefore took precedence over monetary stability and cooperation, and it was only after a fiscal settlement had been reached between domestic constituencies, as well as between the allies and the defeated powers, that a coordinated attempt to recover the prewar liberal order was possible. Capital controls were extensively used to phase-in the macro adjustments necessary to stabilise the currencies and the balance of payments at the new parities. British authorities, in particular, were no longer prepared to passively accept capital openness and started weighing it against other considerations of national interest (Atkin 1970, Daunton 2007). An informal embargo on foreign capital issues in London was imposed by the Bank of England as part of its strategy to return sterling to gold, although it was relinquished in 1925 under the impression that it was not enforceable because of the flight of capital to New York. French authorities, faced with bear speculation against the franc and capital flight, oscillated in experimenting with harsh controls or with leaning against the depreciation trend of the franc through interventions in the foreign exchange market. The predictable outcome of these naïve policies was the loss of reserves (Blancheton 2004, Obstfeld and Taylor 2004). Nevertheless, by 1927 the majority of countries had stabilised their currencies and dismantled the bulk of capital controls. The respite would be very brief.

Another debilitating blow to the prewar financial architecture was the ideological challenge to international liberalism posed first by the Soviet Union and later by rightwing regimes in Southern and Eastern Europe. This, however, would become especially salient under the stress of the second and larger shock of the period - the Great Depression. This is not the place to review the long literature on the causes of the Depression, but suffice it to say that its consequences were much aggravated by the combination of autarkic policies and exchange rate rigidity adopted by many nations during the early 1930s (James 2001, Eichengreen 1992). Tariffs and foreign exchange controls or outright devaluation were used by authorities around the globe to control their terms-of-trade. Since these instruments were partly substitutable, countries varied in their choice of policy mix. Countries that devalued more resorted less to tariffs (Eichengreen and Irwin 2009), while countries that devalued less or not at all, such as the 'exchange control' countries connected to Nazi Germany and Latin American nations, imposed bilateral exchange accounts on their trade partners (Figure 1). Many of these nations were also net debtors and used this device to force the payment of their debts in domestic currency -instead of foreign exchange-, deposited in special 'blocked accounts' that creditor nations could only use to buy the debtor's goods or to reinvest in the debtor's economy (a default in everything but the name).

Fiscal redistribution and strategic trade policy were not the single drivers of the backlash against globalisation, particularly with respect to trade policy, but they seem to have played the larger role in driving countries to block or distort their financial links with other nations. This stands in contrast to the prewar period where macro 
policy effects came second to partisan price effects in explaining the generalised capital account openness. Research on the trade and migration components of this backlash is, again, more advanced than on the political economy of capital controls. However, emerging nations were particularly vulnerable to the collapse in international trade during the Depression as they typically specialised in exporting a small range of commodities priced competitively in the world market. The ensuing decline in terms-of-trade was serious enough to lead to a re-evaluation of these nations' positions in the international economy. This came to be known as the 'dependency theory' of immiserizing trade and capital flows from which the developing nations were better advised to protect themselves (Singer 1950, Prebisch 1950). Latin American nations were the first to go down this path by adopting importsubstitution industrialisation in the 1930s as an autarkic growth model, based on distortions to the patterns of trade and capital flows, and controls on foreign ownership of domestic productive assets (Thorp 1984). One can speculate here on the partisan price effects that selected Latin America for this early reverse in policy stance. Falling trade in the Heckscher-Ohlin model reverses the economic interests of the several factor owners relative to the case of increasing integration as alluded before. ${ }^{35}$ The owners of scarce resources benefit in relative terms from disintegration and have an incentive to promote it. Latin American nations were mostly abundant in natural resources and scarce in capital and labour. We are therefore not to be surprised by the 'populist' turn of political events in these nations in the 1930s when urban coalitions wrested the political power from the traditional landowning elites (Rogowski 1989). Financial incumbents would stand to gain from joining this coalition, as the closure to foreign capital would increase their market power and rents (Rajan and Zingales 2003). The example would be copied, after the war, by the growing number of newly independent (and capital-poor) nations in Africa and Asia.

In any case, even in advanced nations, financial liberalisation was now less popular. As these countries recovered from the Depression, a new responsibility was taken by the state, at first haphazardly, and later legitimised by Keynes in the General Theory -that of stabilising the business cycle. The greater salience subsequently of the domestic equilibrium of prices and unemployment changed the order of priorities away from capital openness and toward domestic policy autonomy, and, becoming entrenched after World War II. The postwar politicians, as Keynes in the second quotation in the introduction to this paper, no longer believed that peace and prosperity could be entrusted to the self-ordering of free trade and factor movements. The new international organisations created after the war (IMF, World Bank, UN)

\footnotetext{
35 Another indication of the reversal in economic, outside the Heckscher-Ohlin logic comes from Taylor and Wilson (2006), who notice that the strength of the relation between trade and financial flows was lower in the interwar than before the War. According to the authors this reflected not only the higher transactions costs of trade in the period but also the shorter time available for the new hegemonic power -the US- to establish a track record of financial leadership (Kindleberger 1986).
} 
reflected this move towards positive action in regulating economic relations and promoting cooperation between nations. 


\section{Conclusions}

For the topic of his Nobel Prize Lecture, Robert Mundell chose to reconsider the history of the twentieth century (Mundell 1999). The main conclusion of this lecture was that the stability of the international monetary system depends on the power configuration of the core countries that lead it. In contrast to the nineteenth-century, when Britannia ruled the waves as well as the markets, Mundell blames the economic, monetary, and even political disturbances of the next century on the rise of the US and on the policy mistakes of its monetary arm, the Federal Reserve. This line of argument had been pursued previously by authors such as Kindleberger (1986), who subscribe to an hegemonic theory of economic and political stability. Hegemons are the linchpin of international stability, particularly when providing necessary leadership at critical moments. The British steadfast adherence to this position before the war, the story goes, and the unable or clumsy use of its new-fangled power by the US in the interwar explained the marked contrast in terms of international growth and stability between the two periods.

Even if we don't entirely agree with Mundell and Kindleberger, the interpretation they provide is consistent with the patterns we observe in financial globalisation and the theoretical explanations marshalled to understand them. The widespread support for capital openness before 1914 was attributed to the complementarities between trade and factor flows, as well as to the network externalities from monetary coordination. In this sense, international financial liberalisation is best understood in the context of the other aspects of the globalisation process prior to the War. Countries that opened up to trade gained in terms of easier access to foreign finance, which gave them the means to invest in transportation and communication infrastructure that would enhance their comparative advantage. The connection also operated for countries with excess savings, since previous trade relations alleviated the informational asymmetries in investing in exotic investment projects or securities. Capital also chased labour toward countries abundant in natural resources but hardly in anything else. Finally, access to foreign capital facilitated a credible adherence to stable exchange rates (in the gold standard) and was made easier by the elimination of the currency risk of foreign investors. This in turn made it possible for countries to specialise in an unprecedented degree, because they were assured that specialisation would not imply a current account constraint in bad times. Although emerging economies were not immune to financial crises and exogenous volatility their openness to foreign finance paid off in faster convergence and higher levels of income. Of course, globalisation if beneficial in aggregate also generates losers, who can block the process for lack of a credible redistribution mechanism of ex-post gains. However, the complementarity between trade and factor flows alleviated these distributional tensions, perhaps helped by the concentration of effective political power in elites that stood to gain more from the process.

The multiple positive feedbacks described meant that only a shock to integration could disturb the system from a path of increasing economic integration. Depending 
on the stability properties of the system, a small shock might be enough to disturb the prewar equilibrium. The two shocks of World War I and the Great Depression were not 'small' in any sense and triggered a course of economic and political disintegration that forms a mirror image of the years before 1914. These trends reduced and then reversed the distribution of economic gains from international liberalisation, which was then quickly reflected in the political fights of the period and the dramatic turn toward autarkic policies, especially after 1929. The extension of the franchise certainly helped in making this possible, although identical policies were taken up in democratic as in un-democratic regimes around the World, from the US and Western Europe, to Latin America and the Far East.

And yet, systemic crises were not new, which begs the question of why they hadn't endangered the liberal status quo before the war. There are several candidates for an answer. Kindleberger and Mundell emphasise the role of the UK in preventing the most serious crises of the prewar period $(1890,1907)$ from threatening the stability of the system. This is a straightforward application of a model of multiple equilibria, selected by the focal points provided by the hegemonic nations. The uncompromising isolationism or inept policies of the US provided the wrong focus. Eichengreen (1992) prefers to stress the cooperation between the authorities of the leading nations as well as the limited franchise that insulated them from short-term political pressure before the War. Cooperation and policy independence were in short supply while the world economy descended in the throes of the Depression. But we might also ask, with O'Rourke and Williamson (1999), whether War and Depression can really be construed as exogenous shocks to which an inept world leader could not react in a stabilising way. The work of these two authors and others has uncovered the latent political tensions from the distributional consequences of prewar globalisation. It is possible to imagine a counterfactual world, without a World War starting in 1914, where these tensions could have lead to a backlash against globalisation anyway. Much harder is to test it though. Compared to tariff policies and immigration restrictions, capital mobility was relatively spared by these anti-globalising forces, which may be a reflection of the less adversarial consequences of capital openness alluded to before. Or it may be that we do not fully understand the connection between economic incentives and political outcomes around financial integration. The example of the literature on the political economy of financial liberalisation in the late twentieth-early twenty-first centuries shows the path for the further research necessary to uncover the historical perspective on this topic. More and better data on capital market frictions and capital flows is a good starting point here. The literature has been arguing perhaps too much from the reconstituted series of capital exports from Britain before 1914 and the US after, without much consideration for the significant differences in the patterns of investment of other capital exporting nations (France and Germany). Only then will we be able to follow on Frieden and Rogowski's "plea to eschew impressionistic generalisations, instead attending consciously to the interests 
and incentives facing all relevant individuals and working up from that point to expectations about behaviour" that can be tested empirically. ${ }^{36}$

${ }^{36}$ Frieden and Rogowski (1996: 47). 


\section{References}

Acemoglu, D., S. Johnson, J. Robinson and Y. Thaicharoen (2003) "Institutional causes, macroeconomic symptoms: volatility, crises, and growth," Journal of Monetary Economics, 50: 49-123.

Adalet, M., and B. Eichengreen (2005) "Current Account Reversals: Always a Problem?” NBER Working Paper No. 11634.

Aizenman, J., M. Chinn and H. Ito (2008) "Assessing the Emerging Global Financial Architecture: Measuring the Trilemma's Configuration Over Time," NBER Working Paper no. 14533.

Alesina A. and G. Tabellini (1989) "External debt, capital flight and political risk," Journal of International Economics, 27(3-4):199-220.

Atkin, J. (1970) "Official Regulation of British Overseas Investment, 1914-1931," Economic History Review, 23: 324-35.

Blancheton, B. (2004) "French Exchange Rate Management in the mid-1920s. Lessons Drawn from New Evidence," Cahiers du GRES no. 2204-05.

Barth, B. (1995) Die deutsche Hochfinanz und die Imperialismen. Banken und Außenpolitik vor 1914, Stuttgart: Franz Steiner.

Battilossi, S. (2006) "The determinants of multinational banking during the First Globalization, 1870-1914," European Review of Economic History, 10 (3): 361388 .

Bhagwati, J. (1958) "Immiserizing Growth: A Geometrical Note," Review of Economic Studies, 25: 201-05.

Bhagwati, J. and R. Brecher (1980) "National Welfare in an Open Economy in the Presence of Foreign-Owned Factors," Journal of International Economics, 10: $103-15$.

Bordo, M. (2006) "Sudden stops, financial crises and original sin in emerging countries: déjà vu?” NBER Working Paper no. 12393.

Bordo M., A. Cavallo and C. Meissner (2010) "Sudden Stops: Determinants and Output Effects in the First Era of Globalization, 1880-1913," Journal of Development Economics, 91(2): 227-41.

Bordo, M., B. Eichengreen, D. Klingebiel and S. Martínez-Peria (2001) "Is the Crisis Problem Growing More Severe?" Economic Policy, 16: 51-82.

Bordo, M. and M. Flandreau (2003) "Core, Periphery, Exchange Rate Regimes, and Globalization" in M. Bordo, A. Taylor and J. Williamson, eds., Globalization in 
Historical Perspective, Chicago: Chicago: University of Chicago Press, pp. 41768.

Brune, N., G. Garrett, A. Guisinger, and J. Sorens (2001) "The Political Economy of Capital Account Liberalization," Presented at the 97th annual meeting of the American Political Science Association, San Francisco.

Cain, P. and A. Hopkins (1980) "The Political Economy of British Expansion Overseas, 1750-1914," Economic History Review, 33(4):, 463-90

Calomiris, C. (2005) "Capital Flows, Financial Crises, and Public Policy" in M. Weinstein, ed. Globalization: What's New?, New York: Columbia University Press, pp. 37-76.

Catão, L. (2006) "Sudden Stops and Currency Drops: A Historical Look," IMF Working Paper no. 06/133.

Calvo, G. and E. Mendonza (1996) "Petty Crime and Cruel Punishment: Lessons from the Mexican Debacle," American Economic Review, 96(2): 170-75.

Chabot, B. and C. Kurz (2010) "That's Where The Money Was: Foreign Bias And English Investment Abroad, 1866-1907,”Economic Journal, 120: 1056-79.

Charumilind, C., R. Kali and Y. Wiwattanakantang (2006) "Connected Lending: Thailand Before the Financial Crisis,” Journal of Business, 79(1): 181-218.

Claasen, E.-M. (1985) "Kapitalverkehrskontrollen und ihre Auswirkungen auf Ersparnisse und Investitionen," Der Volkswirtschaftliche Sparprozeß. Beihefte zu Kredit und Kapital, no. 9: 715-33.

Daudin, G., M. Morys and K. O'Rourke (2010) "Globalization, 1870-1914" in S. Broadberry and K. O'Rourke, eds, The Cambridge Economic History of Modern Europe. Vol 2, 1870 to the Present, Cambridge: Cambridge University Press, pp. 5-29.

Daunton, M. (1989) “Gentlemanly Capitalism' and British Industry, 1820-1914”, Past and Present, 122: 119-58.

Daunton, M. (2006) "Britain and Globalisation since 1850: I. Creating a Global Order, 1850-1914," Transactions of the Royal Historical Society, 16: 1-38.

Daunton, M. (2007) "Britain and Globalisation since 1850: II. The Rise of Insular Capitalism, 1914-1939," Transactions of the Royal Historical Society, 17: 1-3.

Davis, L. and R. Huttenback (1986) Mammon and the Pursuit of Empire. The Political Economy of British Imperialism, 1860-1912, Cambridge: Cambridge University Press. 
Dornbusch, R. (1976) "Expectations and Exchange Rate Dynamics," Journal of Political Economy, 84: 1161-76.

Dreher, A. and L. Siemers (2009) "The nexus between corruption and capital account," Public Choice, 140: 245-65.

Edelstein, M. (1982) Overseas Investment in the Age of High Imperialism. The United Kingdom, 1850-1914, London: Methuen.

Edelstein, M. (1994) "Foreign Investment and Accumulation, 1860-1914," in R. Floud and D. McCloskey, eds., The Economic History of Britain Since 1700. Vol. 2: 1860-1939, Cambridge: Cambridge University Press, 2nd ed., pp. 173-96.

Eichengreen, B. (1992) GoldenFetters. The Gold Standard and the Great Depression, 1919-1939, New York: Oxford University Press.

Eichengreen, B. (2004) Capital Flows and Crises, Cambridge, Mass: MIT Press.

Eichengreen, B. and M. Bordo (2003) "Crises Now and Then: What Lessons from the Last Era of Financial Globalization?" in P. Mizen, ed., Monetary History, Exchange Rates and Financial Markets: Essays in Honor of Charles Goodhart, Vol. 2, London: Edward Elgar, pp. 52-91.

Eichengreen, B. and D. Irwin (2009) "The Slide to Protectionism in the Great Depression: Who Succumbed and Why?” NBER Working Paper no. 15142.

Eichengreen, B. and D. Leblang (2008) "Democracy And Globalization," Economics and Politics, 20(3): 289-334.

Esteves, R. (2007) "Between Imperialism and Capitalism. European Capital Exports before 1914," University of Oxford: Mimeo.

Esteves, R. (2011) "The Belle Epoque of International Finance. French Capital Exports, 1880-1914," Oxford University, Department of Economics Discussion Paper no. 534.

Esteves, R. and D. Khoudour-Castéras (2009) "A Fantastic Rain of Gold. European Migrants' Remittances and Balance of Payments Adjustment During the Gold Standard," Journal of Economic History, 69(4): 951-85.

Esteves, R. and D. Khoudour-Castéras (2011) “"Remittances, Capital Flows and Financial Development during the Mass Migration Period, 1870-1913," European Review of Economic History, forthcoming.

Feis, H. (1930) Europe, the World's Banker, 1870-1914. An account of European foreign investment and the connection of world finance with diplomacy before the War, New Haven: Council on Foreign Relations. 
Feldstein, M. and C. Horioka (1980) "Domestic Saving and International Capital Flows," Economic Journal, 90: 314-29.

Fenoaltea, S. (1988) "International Resource Flows and Construction Movements in the Atlantic Economy: The Kuznets Cycle in Italy, 1861-1913." Journal of Economic History, 48(3): 605-37.

Fishlow, A. (1985) "Lessons From the Past: Capital Markets During the 19th Century and the Interwar Period," International Organization, 39: 38-93.

Flandreau, M. and F. Gallice (2005) "Paris, London and the International Money Market: Lessons from Paribas 1885-1913" in Y. Cassis and E. Bussière, eds., London and Paris as International Financial Centres in the Twentieth Century, Oxford: Oxford University Press: 78-106.

Flandreau, M. and M. Maurel (2005) "Monetary Union, Trade Integration, and Business Cycles in 19th Century Europe: Just Do It," Open Economies Review, 16: $135-52$.

Flood, R. and P. Garber (1984) "Collapsing Exchange-Rate Regimes, Some Linear Examples," Journal of International Economics, 17: 1-13.

Fogel, R. (1967) "The Specification Problem in Economic History," Journal of Economic History, 27: 283-308.

Frieden, J. and R. Rogowski (1996) "The impact of the international economy on national policies," in R. Keohane and H. Milner, eds., Internationalization and domestic politics, New York: Cambridge University Press, pp. 25-47.

Gallarotti, G. (1995) The Anatomy of An International Monetary Regime: The Classical Gold Standard, 1880-1914, New York: Oxford University Press.

Garrett, G. (2001) "Globalization and Government Spending around the World," Studies in Comparative International Development, 35(4): 3-29.

Gerschenkron, A. (1962) Economic Backwardness in Historical Perspective, Cambridge: Harvard University Press.

Goetzmann, W. (2004) "Will History Rhyme?," Journal of Portfolio Management, 30(5): 34-41.

Goetzmann W. and A. Ukhov (2006) "British Investment Overseas 1870-1913: A Modern Portfolio Theory Approach," Review of Finance, 10(2): 261-300.

Gourinchas, P.-O. and O. Jeanne (2006) "The Elusive Gains from International Financial Integration," Review of Economic Studies, 73(3): 715-41. 
Harley, K. (2000) “A Review of O'Rourke and Williamson's Globalization and History: The Evolution of a Nineteenth Century Atlantic Economy," Journal of Economic Literature, XXXVIII: 926-35.

Hatton, T. and J. Williamson (2005) Global Migration and the World Economy. Two Centuries of Policy and Performance, Cambridge, Mass: MIT Press.

Henry, P. (2007) "Capital Account Liberalization: Theory, Evidence, and Speculation," Journal of Economic Literature, 45(4): 887-935.

Hilferding, R. (1920) Das Finanzkapital: eine Studie über die jüngste Entwicklung des Kapitalismus, Vienna: Verlag der Wiener Volksbuchhandlung, 2nd ed.

Hobson, J. (1902) Imperialism: A Study, New York: James Pott and Co.

James, H. (2001) The End of Globalization: Lessons from the Great Depression, Cambridge, Mass: Harvard University Press.

Jeanne, O. (2000) "Currency Crises: A Perspective on Recent Theoretical Developments," Centre for Economic Policy Research Discussion Paper no. 2170.

Johnson, H. (1967) "The Possibility of Income Losses from Increased Efficiency or Factor Accumulation in the Presence of Tariffs," Economic Journal, 77: 151-54.

Kalemli-Ozcan, S. and A. Nikolsko-Rzhevskyy (2010) "Does Trade Cause Capital to Flow? Evidence from Historical Rainfalls," NBER Working Paper no. 16034.

Kaminsky, G., C. Reinhart and C. Végh (2003) "The Unholy Trinity of Financial Contagion," Journal of Economic Perspectives, 17(4): 51-74.

Kemp, M. (1966) "The Gain from International Trade and Investment: A New Heckscher-Ohlin Approach," American Economic Review, 56: 788-809.

Keynes, J. M. (1971 [1919]) The Collected Writings of John Maynard Keynes. Volume II The Economic Consequences of Peace, London: Macmillan St Martin's Press.

Keynes, J. M. (1982 [1933]) The Collected Writings of John Maynard Keynes. Volume XXI Activities 1931-1939. World Crises And Policies in Britain and America, London: Macmillan Cambridge University Press.

Kindleberger, C. (1986) The World in Depression, 1929-39 (Revised and Enlarged Edition), Berkeley: University of California Press.

Kose, M., E. Prasad, K. Rogoff, and S.-J. Wei (2006) "Financial Globalisation: A Reappraisal", IMF Working Paper no. 06/189. 
Kose, M., E. Prasad and A. Taylor (2009) "Thresholds in the Process of International Financial Integration,” NBER Working Paper no. 14916.

Krugman, P. (1979) “A Model of Balance-of-Payments Crises," Journal of Money, Credit, and Banking, 11: 311-25.

Krugman, P. (1996) “Are Currency Crises Self-Fulfilling?” NBER Macroeconomics Annual, Cambridge, Mass: MIT Press, pp. 345-77.

Lenin, V. (1934 [1916]) Imperialism: The Highest Stage of Capitalism, London: Martin Lawrence.

Levine, R. (2005) "Finance and Growth: Theory and Ideas" in P. Aghion and S. Durlauf, eds., Handbook of Economic Growth, Vol. 1A, Amsterdam: Elsevier, pp. 865-934.

Lévy-Leboyer, M. (1977) "La balance des paiements et l'exportation des capitaux français" in La position international de la France, Paris: Editions de l'EHESS, pp. 75-142.

Lévy-Leboyer, M. and F. Bourguignon (1985) The French Economy in the Nineteenth Century. An Essay in Econometric Analysis, Cambridge: Cambridge University Press.

MacDougall, G. (1960) "The Benefits and Costs of Private Investment from Abroad: A Theoretical Approach," Economic Record, 36: 13-35.

Marseille, J. (1984) Empire colonial et capitalisme français. Histoire d'un divorce, Paris: Albin Michel.

Martell, R. and R. M. Stulz (2003) "Equity Market Liberalizations as Country IPO's," American Economic Review, 93(2): 97-101.

Mathieson, D. and L. Rojas-Suarez (1994) "Capital controls and capital account liberalization in industrial countries," in L. Leiderman and A. Razin, eds, Capital mobility: the impact on consumption, investment and growth, Cambridge: Cambridge University Press, pp. 329-47.

McCloskey, D. (1970) “Did Victorian Britain Fail?” Economic History Review, 23: 446-59.

McKinnon, R. and H. Pill (1997) "Credible Economic Liberalizations and Overborrowing," American Economic Review, 87(2): 189-93.

Meissner, C. and M. Bordo (2007) "Foreign Capital and Economic Growth in the First Era of Globalization,” NBER Working Paper no. 13577. 
Morris, S. and H. Shin (1998) "Unique Equilibrium in a Model of Self-Fulfilling Currency Attacks," American Economic Review, 88: 587-97.

Müller, J. (1992) Der deutsche Rentenmarkt vor dem Ersten Weltkrieg - eine Indexanalyse, Frankfurt am Main: Fritz Knapp.

Mundell, R. (1999) "A Reconsideration of the Twentieth Century," Nobel Prize in Economics documents 1999-5, Nobel Prize Committee.

Murphy, K., A. Shleifer and R. Vishny (1989) "Industrialization and the Big Push," Journal of Political Economy, 97(5): 1003-26.

Obstfeld, M. (1986) "Rational and Self-Fulfilling Balance of Payments Crises," American Economic Review, 76: 72-81.

Obstfeld, M. (1996) "Models of Currency Crises with Self-Fulfilling Features," European Economic Review, 40: 1037-47.

Obstfeld, M. and A. Taylor (2004) Global capital markets : integration, crisis, and growth, Cambridge: Cambridge University Press.

O'Rourke, K. and J. Williamson (1999) Globalization and History. The Evolution of a Nineteenth-Century Atlantic Economy, Cambridge, Mass: MIT Press.

O'Rourke, K. and A. Taylor (2007) "Democracy and Protectionism" in T. Hatton, K. O'Rourke and A. Taylor, eds., The New Comparative Economic History. Essays in Honor of Jeffrey G. Williamson, Cambridge, Mass.: MIT Press, pp. 193-216.

Parent, A. and C. Rault (2004) "The Influences Affecting French Assets Abroad Prior to 1914," Journal of Economic History, 64 (2): 328-62.

Porter, A. (1990) 'Gentlemanly capitalism' and empire: The British Experience since 1750?” Journal of Imperial and Commonwealth History, 18(3): 265-95.

Prebisch, R. (1950) The Economic Development of Latin America and Its Principal Problems, New York: United Nations Council for Latin America.

Quinn, D. (1997) "The Correlates of Change in International Financial Regulation," American Political Science Review, 91(3): 531-51.

Quinn, D. and C. Inclán (1997) "The Origins of Financial Openness: A Study of Current and Capital Account Liberalization," American Journal of Political Science, 41(3): 771-813.

Quinn, D. (2003) "Capital Account Liberalization and Financial Globalization, 18901999: A Synoptic View," International Journal of Finance and Economics, 8: 189204. 
Quinn, D. and A. Toyoda (2007) "Ideology and Voter Preferences as Determinants of Financial Globalization,” American Journal of Political Science, 51(2): 344-63.

Rancière, R., A. Tornell and F. Westermann (2008) "Systemic Crises and Growth," Quarterly Journal of Economics, 123(1): 359-406.

Radelet, S. and J. Sachs (1998) "The East Asian Financial Crisis: Diagnosis, remedies, prospects," Brookings Papers on Economic Activity, 1: 1-74.

Rajan, R. and L. Zingales (2003) "The great reversals: the politics of financial development in the twentieth century," Journal of Financial Economics, 69: 5-50.

Reinhart, C. and K. Rogoff (2009) This Time Is Different: Eight Centuries of Financial Folly, Princeton: Princeton University Press.

Rogoff, K. (1999) "International institutions for reducing global financial instability," Journal of Economic Perspectives, 13(4): 21-42.

Rogoff, K. (1999) "International institutions for reducing global financial instability," Journal of Economic Perspectives, 13(4): 21-42.

Rogowski, R. (1989) Commerce and Coalitions: How Trade Affects Domestic Political Alignments, Princeton: Princeton University Press.

Rubinstein, W. (1987) Elites and the Wealthy in Modern British History, Brighton: Palgrave Macmillan.

Schaefer, K. (1993) Deutsche Portfolioinvestitionen im Ausland 1870-1914. Banken, Kapitalmärkte und Wertpapierhandel im Zeitalter des Imperialismus, Münster: LIT.

Schularick, M. and A. Taylor (2010) "Credit booms gone bust: monetary policy, leverage cycles and financial crises, 1870-2008,” NBER Working Paper no. 15512.

Schulze, G. (2000) The Political Economy of Capital Controls, Cambridge: Cambridge University Press.

Simmons, B., and Z. Elkins (2004) "The Globalization of Liberalization: Policy Diffusion in the International Political Economy," American Political Science Review 98(1): 171-89.

Singer, W. (1950) "The Distribution of Gains Between Investing and Borrowing Countries," American Economic Review, 40: 473-85.

Steinmetz, W. (1913) Die Deutschen Großbanken im Dienste des Kapitalexports, Luxemburg: Druckerei der St.Paulus-Gesellschaft. 
Stiglitz, J. (2000) "Capital Market Liberalization, Economic Growth and Instability," World Development, 28: 1075-86.

Stone, I. (1999) The Global Export of Capital from Great Britain, 1865-1914. A Statistical Survey, London: Macmillan

Taylor, A. and J. Wilson (2006) "International Trade and Finance under the Two Hegemons: Complementarities in the United Kingdom 1870-1913 and the United States 1920-30”, NBER Working Paper no. 12543.

Temin, P. (1987) "Capital Exports, 1870-1914: An Alternative Model," Economic History Review, 40(3): 453-58.

Thorp, R., ed. (1984) Latin America in the 1930s : the role of the periphery in world crisis, London: Macmillan.

Trentmann, F. (1997) "Wealth versus Welfare: the British Left between Free Trade and National Political Economy before the First World War," Historical Research, 70(171): 70-98.

Williamson, J. (2000) "Was It Stolper-Samuelson, Infant Industry or Something Else? World Trade Tariffs 1789-1938,” NBER Working Paper no. 9656.

Williamson, J. (2006) Globalization and the Poor Periphery Before 1950, Cambridge, Mass: MIT Press.

Wright, G. (1990) "The Origins of American Industrial Success, 1879-1940," American Economic Review, 80: 651-68. 


\section{University of Oxford Discussion Papers in Economic and Social History: Recent publications}

73 Leigh A. Gardner, To Take or to Make? Contracting for Legitimacy in the Emerging States of Twelfth-Century Britain (November 2008)

74 Avner Offer, British Manual Workers: From Producers to Consumers, c.1950-2000

75 Pablo Astorga, A Century of Economic Growth in Latin America (January 2009)

76 Scott Andrew Urban: The Name of the Rose: Classifying 1930s Exchange-Rate Regimes (April 2009)

77 David Chacko: Medical Liability Litigation: An Historical Look at the Causes for Its Growth in the United Kingdom (April 2009)

78 Mark Koyama: The Price of Time and Labour Supply: From the Black Death to the Industrious Revolution (September 2009)

79 Cliff Bekar and Clyde Reed: Risk, Asset Markets, and Inequality: Evidence from Medieval England (October 2009)

80 Pablo Astorga, Mean Reversion in Long-Horizon Real Exchange Rates: Evidence from Latin America (January, 2010)

81 C. Knick Harley, Prices and Profits in Cotton Textiles during the Industrial Revolution (May, 2010)

82 Avner Offer, Rachel Pechey and Stanley Ulijaszek, Obesity under affluence varies by welfare regimes: the effect of fast food, insecurity, and inequality (July, 2010)

83 Paul A. David, S. Ryan Johansson and Andrea Pozzi, The Demography of an Early Mortality Transition: Life Expectancy, Survival and Mortality Rates of Britain's Royals, 1500-1799 (August, 2010)

84 Florian Ploeckl, The Zollverein and the Formation of a Customs Union (August, 2010).

85 S. Ryan Johansson, Medics, Monarchs and Mortality, 1600-1800: Origins of the KnowledgeDriven Health Transition in Europe (October, 2010)

86 Luke Samy, 'The Paradox of Success': The Effect of Growth, Competition and Managerial SelfInterest on Building Society Risk-taking and Market Structure, c.1880-1939 (January, 2011)

87 Paul Minoletti, The Importance of Ideology: The Shift to Factory Production and its Effect on Women's Employment Opportunities in the English Textile Industries (February, 2011)

88 Emanuele Felice, The determinants of Italy's regional imbalances over the long run: exploring the contributions of human and social capital (March, 2011)

89 Rui P. Esteves, The Political Economy of Global Financial Liberalization in Historical Perspective (June, 2011) 
UNIVERSITY OF OXFORD DISCUSSION PAPERS IN ECONOMIC AND SOCIAL HISTORY are edited by

Rui Esteves (Brasenose College, Oxford, OX1 4AJ) Florian Ploeckl (Nuffield College, Oxford, OX1 1NF)

Papers may be downloaded from http://www.nuff.ox.ac.uk/Economics/History 